\title{
Evaluation of some Bread Wheat Cultivars Productivity and Quality to Foliar Spray Time by Different ZINC Oxide Nanoparticles Sizes
}

\author{
Ahmed, Rbab S. ${ }^{1}$; K.A. Abd El-Rahman ${ }^{1}$; E.A. Teama ${ }^{1}$; A.H. Galal ${ }^{1}$ and A.A. Othman ${ }^{2}$ \\ ${ }^{1}$ Agronomy Dept., Fac. Agric., Assiut Univ., Egypt \\ ${ }^{2}$ Physics Dept., Fac. Sci., Assiut Univ., Egypt
}

Received on: 8/11/2018

Accepted for publication on: $29 / 11 / 2018$

\begin{abstract}
A field experiment was carried out during 2016/ 2017 and 2017/ 2018 seasons at the Agronomy Department Experimental Farm, Agriculture Faculty, Assiut University to study the effect of foliar spray time by different zinc oxide nanoparticles sizes on productivity and quality of some bread wheat cultivars. The experiment was laid out in randomized complete block design (RCBD) using split plot in strips arrangement with three replications. Zinc dioxide nanoparticles size (control, 20.7, 23.0 and $27.0 \mathrm{~nm}$ ) were allocated horizontally, while, the three bread wheat cultivars (Sids-1, Sids-12 and Gemmeaza-11) were arranged vertically and zinc spray time (30, 45 and 60 days after planting) were assigned in sub plots. The obtained results show that the zinc oxide nanoparticles sizes ( $\mathrm{ZnO}$ NPs), bread wheat cultivars and zinc spray time variables had a significant influence on all studied traits in the two growing seasons except the effect of zinc application time on number of spikes $\mathrm{m}^{-2}$ and grain yield feddan ${ }^{-1}$ traits in the first season which was non- significant. In addition, the most first order interactions had a significant effect on most studied traits in both seasons. Furthermore, the second order interaction had a significant effect on all studied traits in both seasons. The highest mean values of grain yield feddan ${ }^{-1}$ (28.67 and 28.50 ardab feddan $^{-1}$ in the first and second seasons, respectively) were obtained from planting Gemmeza-11 cultivar and sprayed it by minimum size $(20.7 \mathrm{~nm})$ of $\mathrm{ZnO}$ NPs after 60 days from planting. Moreover, sowing Sids-12 cultivar and sprayed it by minimum ZnO NPs size $(20.7 \mathrm{~nm})$ at 30 days after planting recorded the maximum mean value of grains dry gluten content $(13.72 \%)$ in the first seasons, while, the highest mean value of grains dry gluten content $(14.37 \%)$ in the second seasons was achieved from planting Sids-1 cultivar and sprayed it by minimum $\mathrm{ZnO}$ NPs size $(20.7 \mathrm{~nm})$ at 60 days after planting.
\end{abstract}

Keywords: Nano zinc oxide application time, Bread wheat cultivars, grain yield and quality

\section{Introduction}

Wheat crop (Triticum sp. L.) considers the most important cereal crop in the world with regard to cultivated area and production. The cultivated area of wheat in Egypt during 2017/2018 season was about 1.32 million hectares with the total yield production of 8.45 metric ton (USDA, 2018). While the total consumption reached about 19.6 million metric tons. So, increasing wheat production in order to reduce the gap between production and consumption are the strategic aim. Therefore, a great attention should be paid to overcome or minimize the gap between wheat production and consumption, thus increasing production per unit area appears to be the main objective of reducing the wheat gap. Increasing wheat yield per unit area could be attained by cultivating high-yielding cultivars and implement recommended cultural practices. The productivity and quality of wheat depends on several factors like climate, agronomic management practices, varietal response, soil type etc. The response of different wheat genotypes to zinc fertilization can support the expression of $\mathrm{Zn}$-efficient and Zn-inefficient genotypes.

Zinc ( $\mathrm{Zn})$ is considered an essential micronutrient which plays very important role in plant metabolism by influencing the activities of hydrogenase 
and carbonic anhydrase, stabilization of ribosomal fractions and synthesis of cytochrome, plant enzymes activated, carbohydrate metabolism, maintenance of the integrity of cellular membranes, protein synthesis, regulation of auxin synthesis and pollen formation, regulation and maintenance of the gene expression required for the tolerance of environmental stresses in plants (Hafeez et al., 2013).

Nanoparticle is defined based on the size at which fundamental properties differ from those of the corresponding bulk material (Banfield and Zhang, 2001). Nanoparticles overlap in size with colloids, which ranges from $1 \mathrm{~nm}$ to 1 $\mathrm{mm}$ in diameter (Buffle, 2006). Novel properties that differentiate nanoparticles from the bulk material typically develop at a critical length scale of under 100 nm. The "novel properties" mentioned are entirely dependent on the fact that at the Nano-scale, the physics of nanoparticles mean that their properties are different from the properties of the bulk material. Particle size may affect agronomic effectiveness of $\mathrm{Zn}$ fertilizers. Decreased particle size results in increased number of particles per unit weight of applied Zn. Decreased particle size also increases the specific surface area of a fertilizer, which should increase the dissolution rate of fertilizers with low solubility in water such as zinc oxide (Mortvedt, 1992).

Table 1. Some physical and chemical properties of the experimental soil.

\begin{tabular}{|l|c|c|}
\hline \multicolumn{1}{|c|}{ Properties } & $\mathbf{2 0 1 6 / 2 0 1 7}$ & $\mathbf{2 0 1 7 / 2 0 1 8}$ \\
\hline Mechanical analysis: & & \\
Sand & 27.00 & 27.80 \\
Slit & 23.00 & 22.20 \\
Clay & 50.00 & 50.00 \\
Soil type & Clay & Clay \\
Chemical analysis: & & \\
pH & 7.63 & 7.85 \\
Organic matter \% & 1.80 & 1.70 \\
Total N\% & 0.09 & 0.08 \\
\hline
\end{tabular}

Experimental treatments and design:

The experiment was laid out in randomized complete block design (RCBD) using strip split plot ar-
Many investigators detected the differences amoung bread wheat genotypes for grain yield and its attributes as well as quality traits (El-Dahshouri et al., 2017; Farag et al., 2018; Hassanein et al., 2018; Mansour et al., 2018 and Zenhom et al., 2018).

Regarding zinc spray time, ElDahshouri et al. (2017) indicated that the highest wheat grain yield and its components were obtained by foliar application of $\mathrm{Zn}$ at the tillering + stem elongation growth stage followed by the tillering + stem elongation + milking stages, while the lowest mean values were obtained from the control treatment.

The objective of this research was to study the effect of foliar spray time by different zinc oxide nanoparticles sizes on productivity and quality of some bread wheat cultivars.

\section{Materials and Methods \\ Experimental site description:}

This work was carried out during 2016/2017 and 2017/2018 seasons at the Agronomy Department Experimental Farm, Agriculture Faculty, Assiut University to study the effect of foliar spray time by different zinc oxide nanoparticles sizes on productivity and quality of some bread wheat cultivars. The mechanical and chemical analyses of the experimental soil are presented in Table 1.

rangement with three replications. Zinc dioxide nanoparticles size (control, 20.7, 23.0 and $27.0 \mathrm{~nm}$ ) were allocated horizontally, while, bread wheat cultivars (Sids-1, Sids-12 and 
Gemmeaza-11) were arranged vertically and zinc application time (30, 45 and 60 days after planting) were arranged in sub plots. Each sub plot area was $10.5 \mathrm{~m}^{2}$.

\section{Cultural practices:}

Wheat grains were hand sown on $1^{\text {st }}$ and $3^{\text {rd }}$ December in the first and second seasons, respectively. Control plants were sprayed with water (without ZnO NPs) while the others were sprayed by the certain size of $\mathrm{ZnO}$ NPs at the mentioned stages. The ZnO NPs concentration was 300 ppm. The preceding summer crop was maize in both seasons. All other cultural practices recommended for wheat crop were done in both seasons.

\section{Measured traits:}

At harvest a random sample of square meter from each experimental unit was taken and the following traits were recorded: Number of spikes $/ \mathrm{m}^{2}$, kernels weight/spike (g) and thousand kernels weight (g).

Grain yield (Ardab/fed.): All harvested plants for each experimental unit were threshed then grain weighted and transferred into ar$\mathrm{dab} / \mathrm{fed}$. $(\mathrm{ardab}=150 \mathrm{~kg}$, fed. $=4200$ $\mathrm{m}^{2}$ ).

As well as, some quality traits were determined as follows:

Test weight (kg/hectoliter): One -quarter liter apparatus was used to determine the test weight of grains.

Dry gluten content (\%): Gluten content was determined according to the standard method described by American Association of Cereal Chemists (A.A.C.C., 2000) as follows, twenty grams of each sample from the flour were placed in a container. Ten $\mathrm{cm}^{3}$ water were added and mixed then the dough pieces were rolled into balls by hand then it was placed in glass water on hour washed down using a little water and grabs starch and stayed wet gluten content then dried for 48 hours at $70{ }^{\circ} \mathrm{C}$ to determined dry gluten.

Fermentation time (minutes): Ten grams of each sample from flour were putted in container, then $5.5 \mathrm{~cm}^{3}$ ferment (ferment was prepared by solving 100- gram yeast in $1000 \mathrm{ml}$ water) was added and mixed, then the dough pieces were rolled into balls by hand then it was putted in glass contained $80 \mathrm{ml}$ water at $32{ }^{\circ} \mathrm{C}$ until the dough balls were exploded.

\section{Statistical analysis:}

All collected data were analyzed with analysis of variance (ANOVA) Procedures, using the SAS Statistical Software Package v.9.2 (SAS, 2008). Differences between means were compared by revised least significant difference (RLSD) at 5\% level of significant (Gomez and Gomez, 1984).

\section{Results and Discussion}

1- Yield components traits:

1-a. Number of spikes $\mathrm{m}^{-2}$ :

Data in Table 2 reveal that zinc oxide nanoparticles size (ZnO NPS) had a significant $(\mathrm{p} \leq 0.05)$ effect on number of spikes $\mathrm{m}^{-2}$ in both seasons. Minimized zinc nanoparticles size increased number of spikes $\mathrm{m}^{-2}$ and the highest mean values of this traits were obtained from $20.7 \mathrm{~nm}$ of $\mathrm{ZnO}$ NPs which were 501.78 and 473.11 spikes $\mathrm{m}^{-2}$ in the first and second seasons, respectively. Decreased particle size increased number of particles per unit weight of applied Zn, also, increases the specific surface area of a fertilizer, which should increase the dissolution rate of fertilizers with low solubility in water such as zinc oxide (Mortvedt, 1992). Also, Hafeez et al., (2013) suggested that being an essential nutrient $\mathrm{Zn}$ plays a vital role in plant growth and development. Zinc also plays as an activator of enzymes 
in plants and is directly involved in the biosynthesis of auxin, which produces more cells and dry matter that in turn increased number of tillers in wheat which was increased number of spikes $\mathrm{m}^{-2}$.

Moreover, the illustrated data in Table 2 show that the tested bread wheat cultivars varied significantly in number of spikes $\mathrm{m}^{-2}$ in the two growing seasons. Sids-1 cultivars surpassed the others two cultivars in this respect which registered 522. 06 and 485.83 spike $\mathrm{m}^{-2}$ in the two successive seasons, respectively. This is may be due to the genotypic behavior in combination with the environmental conditions, which may be suitable for sids- 1 cultivar than the rest cultivars. These results are in a good line with those obtained by (ElDahshouri et al., 2017; Farag et al., 2018; Hassanein et al., 2018; Mansour et al., 2018 and Zenhom et al., 2018).

Also, the presented in Table 2 focus that the zinc time of application had a highly significant $(p \leq 0.01)$ effect on number of spikes $\mathrm{m}^{-2}$ in the second season only. The foliar spray of $\mathrm{ZnO}$ NPs at 45 days from sowing treatment produced the highest mean value of spikes number $\mathrm{m}^{-2}$ in the second season. Similar trend was obtained by El-Dahshouri et al. (2017).

Here too, the obtained data in Table 2 clear that the most first order interactions had a significant influenced on number of spikes $\mathrm{m}^{-2}$ in both seasons. Furthermore, the exhibited data reveal that the second order interaction had a highly significant $(p \leq 0.01)$ effect on number of spikes $\mathrm{m}^{-2}$ in the two growing seasons. The highest mean values of spikes number $\mathrm{m}^{-2}$ (562.67 and 564.00 spike $\mathrm{m}^{-2}$ in the two respective seasons) were obtained from sids-1 bread wheat culti- var which was sprayed by ZnO NPs $(23 \mathrm{~nm})$ at 30 days after planting in the first season, while the highest mean value in the second season was registered from sids-1 cultivar which was sprayed by ZnO NPs $(20.7 \mathrm{~nm})$ at 60 days after planting. Otherwise, the lowest mean values of spikes number $\mathrm{m}^{-2}$ (408.00 and 328.00 spike $\mathrm{m}^{-2}$ in the two respective seasons) were obtained from Gemmeza-11 bread wheat cultivar sprayed with water (without $\mathrm{ZnO}$ NPs) at 45 days after planting.

\section{1-b. Thousand kernel weight (g):}

It is evident from Table 3 that 1000 kernel weight trait was affected significantly by the studied ZnO NPs in the two growing season. The heaviest grains were obtained from the minimum Zn NPs size $(20.7 \mathrm{~nm})$ which was produced the maximum mean values of thousand kernel weight (45.09 and $48.66 \mathrm{~g}$ in the two respective seasons). The amount of increment in thousand kernel weight due to minimum $\mathrm{ZnO}$ NPs when its compared to control treatment reached about 6.98 and $6.69 \%$ in the first and second seasons, respectively. This may be due to the small size of $\mathrm{ZnO}$ NPs increase the zinc absorption via wheat plants and consequently increased photosynthesis process which led to an increment in metabolic translocation from sources to sinks (kernels) resulted in fill grains. These findings are in harmony with those obtained by Afshar et al. (2014).

Here too, the exhibited data in Table 3 reveal that the tested bread wheat cultivars had a highly significant $(\mathrm{P} \leq 0.01)$ influence on thousand kernels weight in both seasons. Gemmeza-11 bread wheat cultivar recorded the maximum mean values of seed index (48.32 and 52.24 g in the 
two respective seasons). This is may be due to the genotypic behavior in combination with the environmental conditions, which may be suitable for Gemmeza-11 cultivar than the rest cultivars. Similar trend was observed by Noureldin et al. (2013), Solomon and Anjulo (2017) and Farag et al. (2018).

Furthermore, the illustrated data in Table 3 focus that the zinc nanoparticles application time had a significant $(\mathrm{P} \leq 0.05)$ effect on seed index trait in the two growing seasons. Delaying zinc application time to 60 days after planting resulted in an increase in thousand kernel weight as compared to 30 or 45 days after planting. The mean values of thousand kernel weight in the first season which were $43.30,42.37$ and $43.86 \mathrm{~g}$ were obtained when the application time of $\mathrm{ZnO}$ NPs was done at 30, 45 and 60 days after planting, respectively being, $46.97,45.86$ and $47.61 \mathrm{~g}$ in the second season in the same order. These findings are in harmony with those obtained by El-Dahshouri et al. (2017).

Regarding the involved first order interactions in this respect, the data show that the all first order interactions had a highly significant $(\mathrm{P} \leq 0.01)$ effect on 1000 kernel weight in both seasons. Moreover, the second order interaction had a highly significant $(\mathrm{P} \leq 0.01)$ influence on 1000 kernel weight trait in both season. The highest mean value of 1000 kernel weight (50.62 and $56.95 \mathrm{~g}$ ) were obtained from Gemmeza-11 and Sids 12 bread wheat cultivars which was sprayed by minimum size of $\mathrm{ZnO}$ NPs $(20.7 \mathrm{~nm})$ at 30 days after planting, in the first and second seasons, respectively.

1-c. kernels weight spike ${ }^{-1}$ :
It is clear from the data in Table 4 that the $\mathrm{ZnO}$ NPs had a highly significant $(\mathrm{P} \leq 0.01)$ effect on kernels weight spike ${ }^{-1}$ trait in the two growing seasons. Wheat plants which were sprayed by small size $(20.7 \mathrm{~nm})$ of $\mathrm{ZnO}$ NPs produced the highest mean values of kernels weight spike $^{-1}(2.99$ and $3.26 \mathrm{~g}$ in the two respective seasons). This is to be logic since the same treatment produced the highest mean values with regard to 1000 kernel weight (Table 3) and consequently produced the highest mean values of kernel weight spike ${ }^{-1}$. These results are in agreement with those obtained by Afshar et al. (2014).

The illustrated data in Table 4 prove that the studied bread wheat cultivars varied significantly in kernels weight spike $^{-1}$ trait in both seasons. Gemmeza-11 bread wheat cultivar surpassed the others two tested cultivars in this respect and registered the highest mean values of kernels weight spike $^{-1}$ which were 2.97 and $3.59 \mathrm{~g}$ in the first and second seasons, respectively. This is to be logic since the same cultivar surpassed the others two cultivars with regard to 1000 kernel weight trait and consequently gained the highest mean values of kernel weight spike $^{-1}$. Similar trend was observed by Gheith et al. (2013); Noureldin et al. (2013) and Seleem \& Abd El -Dayem (2013).

Furthermore, the presented data in Table 4 reveal that the zinc application time had a significant effect on kernels weight spike ${ }^{-1}$ trait in the first season only. The maximum mean value of kernel weight $\operatorname{spike}^{-1}(2.63 \mathrm{~g})$ in the first season was obtained when $\mathrm{ZnO}$ NPs was sprayed at 45 days after planting.

Moreover, the exhibited data in Table 4 prove that the all involved first order interactions in this respect 
had a significant effect on kernels weight spike $^{-1}$ in the second season only except the interaction between zinc nanoparticles size and cultivars which was significant in both seasons. Also, the second order interaction had a highly significant $(\mathrm{P} \leq 0.01)$ and significant $(\mathrm{P} \leq 0.05)$ effect on kernels weight spike ${ }^{-1}$ in the first and second seasons, respectively. The highest mean value of kernel weight spike $^{-1}(3.20 \mathrm{~g})$ in the first season was obtained from Gemmeza-11 bread wheat cultivar which was sprayed by minimum size of ZnO NPs $(20.7 \mathrm{~nm})$ at 30 days after planting while, the corresponding value $(3.90 \mathrm{~g})$ in the second season was obtained from Gemmeza-11 bread wheat cultivar which was sprayed by ZnO NPs (23.0 $\mathrm{nm})$ at 45 days after planting.

\section{2- Grain yield trait (Ardab feddan ):}

Grain yield feddan ${ }^{-1}$ trait was affected significantly by the tested $\mathrm{ZnO}$ NPs in the two growing seasons (Table 5). The highest mean values in this respect (25.77 and 26.20 ardab feddan $^{-1}$ in the two successive seasons, respectively) were obtained from wheat plants which were sprayed by minimum size of $\mathrm{ZnO}$ NPs $(20.7 \mathrm{~nm})$. While the lowest mean values of grain yield feddan ${ }^{-1}$ (21.95 and 21.20 ardab feddan ${ }^{-1}$ in the first and second seasons, respectively) were obtained from wheat plants which were sprayed by water (control treatment, without $\mathrm{ZnO}$ NPs). The amount of increment between $\mathrm{ZnO} \mathrm{NPs}$ in minimum size $(20.7 \mathrm{~nm})$ and control treatment reached about 17.40 and $23.58 \%$ in the first and second seasons, respectively. This is to be expected since the same trend was observed with regard to number of spikes $\mathrm{m}^{-2}$ (Table 2 ) and kernel weight spike ${ }^{-1}$ (Table 4) traits. Similar trend was observed by Afshar et al. (2014).

Furthermore, the illustrated data in Table 5 reveal that the tested bread wheat cultivars varied significantly at $5 \%$ level of probability in grain yield feddan $^{-1}$ trait in both seasons. The maximum mean values of grain yield (24.62 and 24.81 ardab feddan $^{-1}$ in two respective seasons, respectively) were obtained from Gemmeza-11 bread wheat cultivar. This superiority of Gemmeza-11 bread wheat cultivar due to the superiority in kernels weight spike $^{-1}$. Similar trend was observed by Gheith et al. (2013); Noureldin et al. (2013); Fergani et al. (2014); Elhag (2017) and Farag et al. (2018). On the contrary, these results conflicted with those obtained by Hassanein et al. (2018).

Here to, the presented data in Table 5 prove that the zinc application time treatment had a highly significant $(\mathrm{P} \leq 0.01)$ effect on grain yield feddan $^{-1}$ in the second season only. Foliar spray by zinc oxide nanoparticles at 60 days after planting produced the maximum mean value of grain yield (25.98 ardab feddan ${ }^{-1}$ in the second season).

Moreover, the all involved first order interactions had a significant or highly significant influence on grain yield feddan ${ }^{-1}$ in both seasons except the interaction between cultivars and zinc time of application in the first season (Table 5). This is logic since the same trend was observed with regard to most studied yield components traits.

Furthermore, the illustrated data in Table 5 show that the second order interaction had a significant $(\mathrm{P} \leq 0.05)$ effect on grain yield feddan ${ }^{-1}$ in both seasons. The highest mean values of grain yield feddan ${ }^{-1}(28.67$ and 28.50 ardab feddan ${ }^{-1}$ in the first and second 
seasons, respectively) were obtained from planting Gemmeza-11 bread wheat cultivar which was sprayed by minimum size $(20.7 \mathrm{~nm})$ of $\mathrm{ZnO}$ NPs after 60 days from planting.

\section{Quality traits:}

\section{3-a. Test weight (kg/hectoliter):}

Test weight trait reacted significantly $(\mathrm{P} \leq 0.05)$ to the tested $\mathrm{ZnO}$ NPs in the two growing seasons (Table 6). Minimization zinc nanoparticles size increased this trait in both season. The highest mean values of test weight trait (74.46 and 77.93 $\mathrm{kg} /$ hectoliter in the first and second seasons, respectively) were obtained from wheat plants which were sprayed by minimum size $(20.7 \mathrm{~nm})$ of $\mathrm{ZnO}$ NPs with no significant differences between this size and 23.0 $\mathrm{nm}$ size in both seasons.

Here too, the presented data in Table 6 reveal that the studied bread wheat cultivars varied significantly in test weight trait in both seasons. Sids1 bread wheat cultivar produced the highest mean values of test weight trait which were 75.86 and 78.44 $\mathrm{kg} /$ hectoliter in the two respective seasons. This is may be due to the genotypic behavior in combination with the environmental conditions, which may be suitable for Sids-1 cultivar than the rest cultivars. These findings are in a good line with those obtained by Akgun et al. (2017).

Also, the illustrated data in Table 6 prove that the tested zinc application time treatments had a significant $(\mathrm{P} \leq 0.05)$ influence on test weight trait in both seasons. Zinc foliar spray at 30 days after planting gained the highest mean value of test weight trait $(74.30 \mathrm{~kg} /$ hectoliter $)$ in the first season. While, the highest mean value of test weight trait in the second season (77. $62 \mathrm{~kg} /$ hectoliter) was obtained when $\mathrm{ZnO}$ NPs was sprayed at 60 days after planting with no significant differences between this treatment and spray at 30 days after planting.

Furthermore, the first order interaction between zinc nanoparticles size $\times$ cultivar failed to reach a significant at 5\% level of probability of test weight trait in both seasons (Table 6). Otherwise, the first order interactions between zinc nanoparticles size $\times$ time of application and cultivars $\times$ time of application had a significant effect on test weight trait in both seasons.

Moreover, the exhibited data in Table 6 show that the second order interaction had a highly significant $(\mathrm{P} \leq 0.01)$ and significant $(\mathrm{P} \leq 0.05)$ effect on test weight trait in the first and second seasons, respectively. Sowing Sids-1 cultivar and sprayed it by $\mathrm{ZnO}$ NPs $(23.0 \mathrm{~nm})$ at 30 days after planting produced the highest mean value of test weight $(77.5 \mathrm{~kg} /$ hectoliter) in the first season. On the other hand, sowing Gemmeza-11 cultivar and sprayed it by $\mathrm{ZnO}$ NPs $(20.7 \mathrm{~nm})$ at 60 days after planting produced the highest mean value of test weight $(80.87 \mathrm{~kg} /$ hectoliter $)$ in the second season.

\section{3-b. Grains dry gluten content $(\%)$}

Exhibited data in Table 7 reveal that the tested $\mathrm{ZnO}$ NPs sizes had a highly significant $(\mathrm{P} \leq 0.01)$ influence on dry gluten percentage trait in the two growing seasons. Wheat plants which were sprayed by any $\mathrm{ZnO}$ NPs size surpassed significantly wheat plants which were sprayed with water (control, without $\mathrm{ZnO} \mathrm{NPs}$ ) in this respect. The highest mean values of dry gluten percentage trait (11.02 and $11.39 \%$ in the two respective seasons) were recorded from wheat plants which were sprayed by minimum size of $\mathrm{ZnO}$ NPs (20.7 nm). 
Here too, the presented data in Table 7 show that the studied bread wheat cultivars varied significantly $(\mathrm{P} \leq 0.05)$ with regard to dry gluten percentage in both seasons. Sids-12 bread wheat cultivars superior the other two cultivars in this respect and recorded the highest mean values of grains dry gluten content (10.45 and $11.28 \%$ in the first and second seasons, respectively). This is may be due to the genotypic behavior in combination with the environmental conditions, which may be suitable for Sids-12 cultivar than the rest cultivars. These findings are in a good line with those obtained by ElMarakby et al. (2015) and Mansour et al. (2018).

Furthermore, the presented data in Table 7 focus that the zinc application time had a highly significant $(\mathrm{P} \leq 0.01)$ effect on grains dry gluten content in both seasons. wheat plants which were sprayed by zinc nanoparticles at 60 days after planting recorded the maximum grains dry gluten content (10.50 and $11.40 \%$ in the two respective seasons).

Also, the obtained data in Table 7 reveal that the all first order interactions had a highly significant or significant effect on grains dry gluten content in both seasons except the interaction between zinc nanoparticles size $\times$ zinc application time in the second season and the interaction between cultivars $\times$ zinc application time in the second season which failed to reach a significantly at $5 \%$ level of probability.

Moreover, the second order interaction had a highly significant effect on grains dry gluten content in the two growing seasons. Sowing Sids-12 cultivar and sprayed it by minimum $\mathrm{ZnO}$ NPs size $(20.7 \mathrm{~nm})$ at 30 days after planting produced the highest mean value of grains dry gluten content $(13.72 \%)$ in the first seasons. While, the highest mean value of grains dry gluten content (14.37 $\%$ in the second seasons was achieved from planting Sids-1 cultivar and sprayed it by minimum $\mathrm{ZnO}$ NPs size $(20.7 \mathrm{~nm})$ at 60 days after planting.

\section{3-c. fermentation time (minutes):}

The recorded data in Table 8 denote that zinc oxide nanoparticles size $(\mathrm{ZnO} \mathrm{NPs})$ had a significant $(\mathrm{P} \leq$ $0.05)$ and highly significant $(P \leq 0.01)$ effect on fermentation time trait in the first and second seasons, respectively. Thus, all tested $\mathrm{ZnO}$ NPs sizes surpassed significantly control treatment (without $\mathrm{ZnO}$ NPs) in this respect in both seasons. The highest mean values of fermentation time trait (44.08 and 45.56 minutes in the two respective seasons) were recorded from wheat plants which were sprayed by minimum size of $\mathrm{ZnO}$ NPs $(20.7 \mathrm{~nm})$. This is to be logic since the same trend was observed with regard to dry gluten trait.

Furthermore, the exhibited data in Table 8 prove that the studied bread wheat cultivars varied in fermentation time seasons. Sids-12 cultivar registered the maximum time of fermentation test which were 41.80 and 45.17 minutes in the first and second seasons, respectively. This is to be expected since the same cultivar surpassed the rest cultivars in dray gluten trait and consequently recorded the maximum mean values of fermentation time.

Here too, the data presented in Table 8 reveal that the zinc application time had a significant $(\mathrm{P} \leq 0.05)$ and highly significant $(\mathrm{P} \leq 0.01)$ effect on fermentation time trait in the first and second seasons, respectively. The maximum mean values of fer- 
mentation time trait (40.00 and 45.60 minutes in the two respective seasons) were obtained from wheat plants which were sprayed by $\mathrm{ZnO}$ NPs at 60 days after planting. This is to be logic since the same trend was observed with regard to dry gluten trait.

Concerning the interaction effect, data in Table 8 reveal that the all involved first order interactions had a highly significant effect on fermentation time in both seasons. In addition, the second order interaction had a highly significant influence on fermentation time in the two growing seasons. Thus, planting Sids-12 cultivar and sprayed it by minimum $\mathrm{ZnO}$ NPs size $(20.7 \mathrm{~nm})$ at 30 days after planting produced the maximum mean value of fermentation time (54.88 minute) in the first seasons. while, the maximum mean value of fermentation time (57.48 minute) in the second seasons was achieved from planting Sids-1 cultivar and sprayed it by minimum $\mathrm{ZnO}$ NPs size $(20.7 \mathrm{~nm})$ at 60 days after planting. This is logic since the same trend was observed with regard to grains dry gluten content trait.

\section{References}

A.A.C.C. (2000). Approved Methods of the American Association Cereal Chem. St. Paul, MN, U.S.A. Am. Assoc. Cereal Chem.

Afshar, I.; R. Akbar and S. Minoo (2014). Comparison of the effects of spraying different amounts of nano $\mathrm{ZnO}$ and bulk $\mathrm{ZnO}$ on wheat. Int. J. Plant, Animal and Env. Sci., 4: 688-693.

Akgun, I.; R. Karaman; F. Eraslan and M. Kaya (2017). Effect of Zinc on Some Grain Quality Parameters in Bread and Durum Wheat Cultivars. Univ. J. Agric. Res., 5(1): 3944.
Banfield, J.F. and H. Zhang (2001). Nanoparticles in the Environment. In "Nanoparticles and the Environment" (J. F. Banfield and A. Navorotsky, Eds,), Mineralogical Society of America, Washington, DC Chapter 1. pp. 1-58.

Buffle, J. (2006). The key role of environmental colloids/nanoparticles for the sustainability of life. Environ. Chem., 3: 155-158.

El-Dahshouri, M.F.; M. M. El-Fouly; R. K. M. Khalifa and H. M. A. ElGhany (2017). Effect of zinc foliar application at different physiological growth stages on yield and quality of wheat under sandy soil conditions. Agricultural Engineering International: CIGR Journal, Special issue: 193-200.

Elhag, D.A.A. (2017). Effect of Irrigations Number on Yield and Yield Components of Some Bread Wheat Cultivars in North Nile Delta of Egypt. Egypt. J. Agron., 39 (2):137- 148.

El-Marakby, A.M.; M.T. Afaf; S.H. Saleh; F.S.A. Samie and Y.A. ElGabery (2015). Performance and stability of some bread wheat genotypes for grain yield, protein and gluten contents under different environmental conditions. Arab Univ. J. Agric. Sci., 23(1):75-87.

Farag, S.A.; S.K.A. Ismail and S.A. ElSsadi (2018). Estimating Phenotypic and Genotypic Path Coefficient, an Application on Wheat (Triticum aestivum L.) Genotypes. Int. J. Curr. Microbiol. App. Sci., 7(2): 2494-2505.

Fergani, M.A. ; M.S. El-Habbal; M. E. El-Temsah(2014). Interpretation of three wheat cultivars yield and its components with reference to sowing dates. Arab Univ. J. Agric. Sci., 22 (1):77-82.

Gheith, E.M.S.; O.Z. El-Badry and S.A. Wahid (2013). Sowing Dates and 
Nitrogen Fertilizer Levels Effect on Grain Yield and its Components of Different Wheat Genotypes. Res. J. Agric. and Biol. Sci., 9(5): 176-181.

Gomez, K.A. and A.A. Gomez (1984). Statistical Procedures for Agricultural Research. $2^{\text {nd }}$ Edn., John Wily and Sons, New York, pp: 68.

Hafeez, B.; Y.M. Khanif and M. Saleem (2013). Role of Zinc in Plant Nutrition- A Review. American J. Experimental Agric.,3(2):374-391.

Hassanein, M.S.; A.G. Ahmed and N.M. Zaki (2018). Effect of nitrogen fertilizer and bio-fertilizer on yield and yield components of two wheat cultivars under sandy soil. Middle East J. Appl. Sci., 8(1): 3742.

Mansour, H.A.; E.I. Eldardiry and M. Abd El-Hady (2018). The Effect of Different Irrigation systems, Nitrogen Levels and Egyptian Wheat Varieties on Flour Quality Parameters. Europ. J. Acad. Essays 5(5): 159-167.

Mortvedt, J.J. (1992). Crop response to level of water soluble zinc in granular zinc fertilizers. Fertilizer Res., 33: 249-255.
Noureldin, N.A.; H.S. Saudy; F. Ashmawy and H. M. Saed (2013). Grain yield response index of bread wheat varieties as influenced by nitrogen levels. An. Agric. Sci., 58(2): 147-152.

SAS institute (2008). The SAS System for Windows, release 9.2. Cary NC: SAS institute.

Seleem, S.A. and S.M. Abd El -Dayem (2013). Response of some wheat cultivars to nitrogen fertilizer levels. J. Plant Production, Mansoura Univ., 4 (5): 721 - 731.

Solomon, W. and A. Anjulo (2017). Response of Bread Wheat Varieties to Different Levels of Nitrogen at Doyogena, Southern Ethiopia. Int. J. Sci. and Res. Public., 7(2): 452459.

USDA (2018). Htpp://apps.fsa. usda.gov/psolonline/ circulars/production.

Zenhom, M.F.T.; G.Y. Hammam and S.A.S. Mehasen (2018). Wheat Lodging and Yield in Response to Cultivars and Foliar Application of Paclobutrazol. $4^{\text {th }}$ International Conference on Biotechnology Applications in Agriculture (ICBAA), Benha University, Moshtohor and Hurghada, 4-7 April 2018, Egypt. 
Doi: 10.21608/ajas.2018.26938

Ahmed, et al., 2018

http://ajas.journals.ekb.eg/ 
Doi: 10.21608/ajas.2018.26938

Ahmed, et al., 2018

http://ajas.journals.ekb.eg/ 
Doi: 10.21608/ajas.2018.26938

Ahmed, et al., 2018

http://ajas.journals.ekb.eg/ 
تقييم إنتاجية وجودة بعض أصناف قمح الخبز لوقت الرش الورقي بأحجام نانومتريه مختلفة من

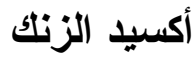

ريبسيد لحمد'، كامل ظي عبد الرهن'، المهاي عبد المطب المهيطعيمة'، انعام حلميجلال وغي عبد الحميد

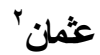

'قسم المحاصيل- كلية الزر اعة - جامعة اسيوط

'قَّم الفيزياء- كلية العلوم - جامعة اسيوط الفيوط

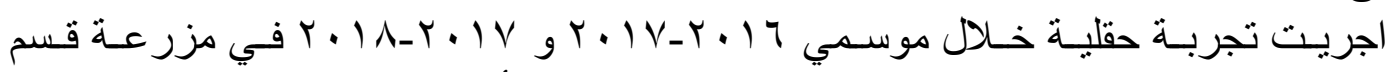

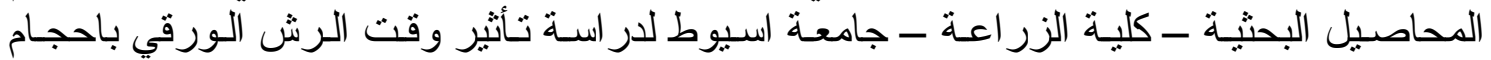

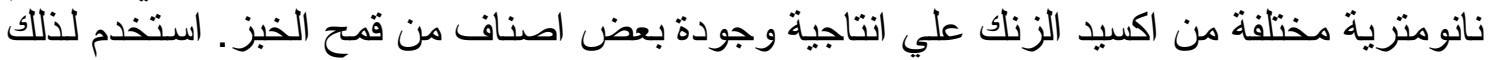

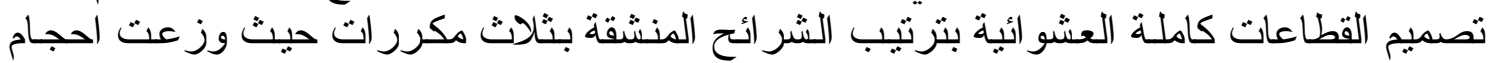

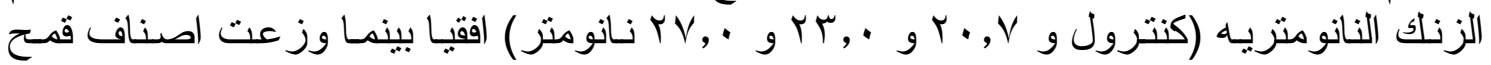

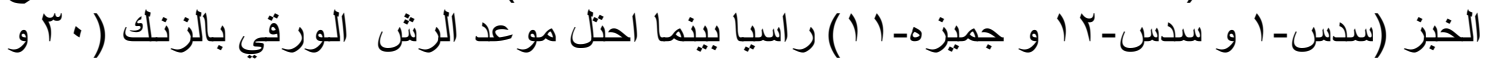

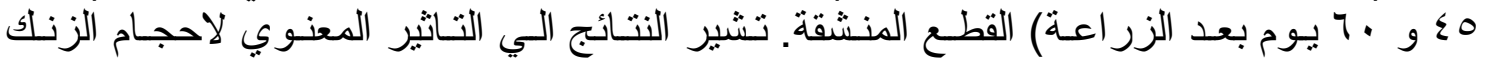

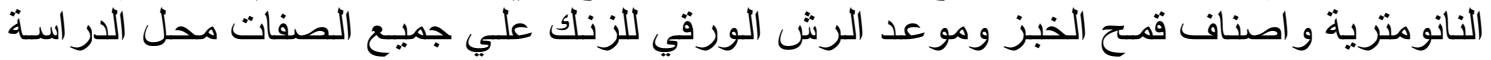

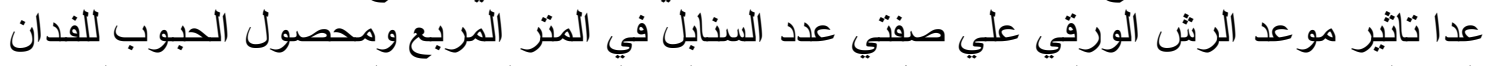

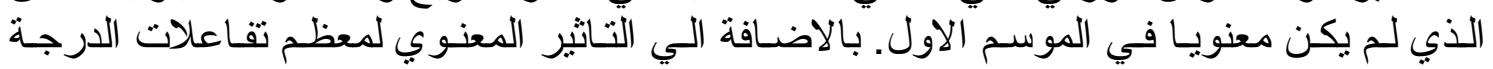

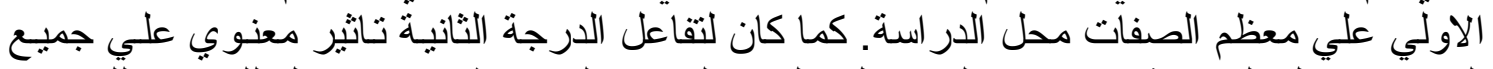

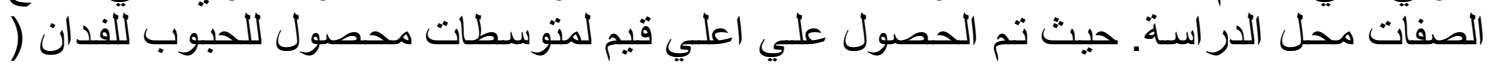

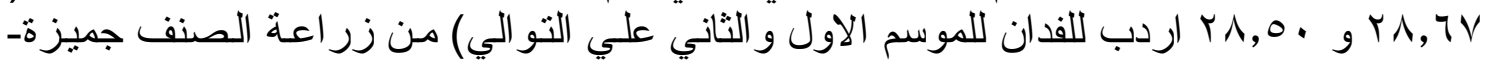

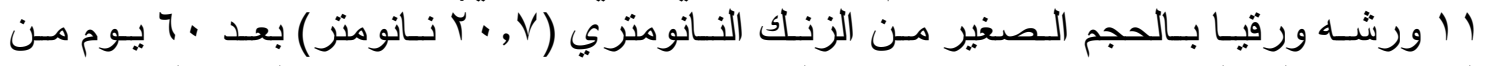

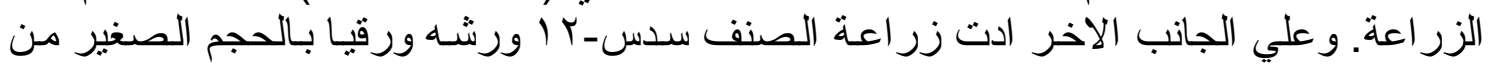

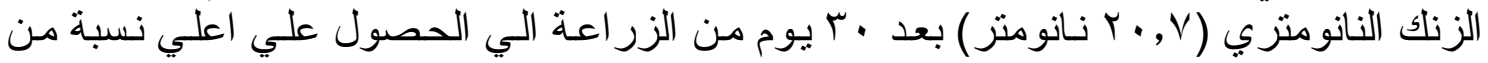

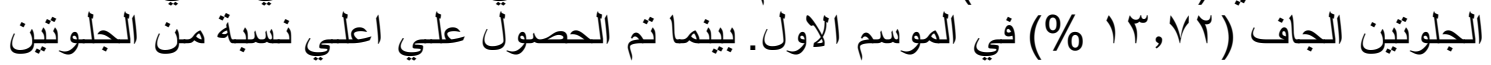

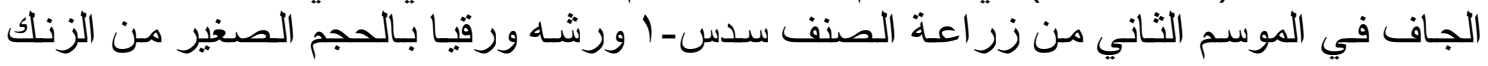

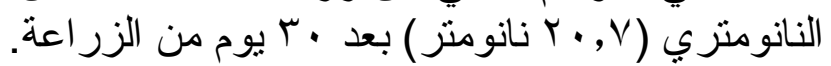

